\title{
Methods of Teaching Reading to EFL Learners: A Case Study
}

\author{
Dedi Sanjaya (Corresponding Author) \\ College of Arts and Sciences, Universiti Utara Malaysia, Malaysia \\ Faculty of Languages and Arts, Universitas Negeri Medan, Indonesia \\ E-mail: sanjayadedihasibuan@gmail.com \\ Rahmah \\ Faculty of Languages and Arts, Universitas Negeri Medan, Indonesia \\ E-mail: rahmah@yahoo.com \\ Johan Sinulingga \\ Faculty of Languages and Arts, Universitas Negeri Medan, Indonesia \\ E-mail: Johan_sinulingga@gmail.com \\ Azhar Aziz Lubis \\ Faculty of Languages and Arts, Universitas Negeri Medan, Indonesia \\ E-mail: azharfbs@gmail.com \\ Muhammad Yusuf \\ Faculty of Languages and Arts, Universitas Negeri Medan, Indonesia \\ E-mail: yusufelmahbub@gmail.com
}

Received: 04-02- 2013

Accepted: 18-03-2013

Published: $30-04-2014$

doi:10.7575/aiac.ijels.v.2n.2p.9

URL: http://dx.doi.org/10.7575/aiac.ijels.v.2n.2p.9

\begin{abstract}
Methods of teaching reading skill are not the same in different countries. It depends on the condition and situation of the learners. Observing the method of teaching in Malaysia was the purpose of this study and the result of the study shows that there are 5 methods that are applied in classroom activities namely Grammar Translation Method (GTM), Direct Method (DM), Communicative Language Teaching (CLT), Audio Lingual Method (ALM) and Silent Way (SW). Through these methods, the students and the teacher can reach the purpose of teaching reading. From this study, it can be concluded that combining more than one method is one of the better ways for the teaching reading skill to EFL learners.
\end{abstract}

Keywords: Method, Reading Skill, and EFL Learners

\section{Introduction}

The classroom that we observed was an Intensive English Course (IEC) at Universiti Utara Malaysia (UUM). A course in English as Foreign Language (EFL) was taking place in that classroom. The class was in BKBM 1.5 Language Centre, Universiti Utara Malaysia. The class started at 09.30 a.m. and finished at 11.30 a.m. The 20 students in the IEC class were adults. They were postgraduate students at UUM but they had not started their study program yet because their ability to communicate in English still needed to be improved. Actually, most of the students were from different fields of study programs at UUM e.g. Business, Law, and Information Technology (IT). This class was in intermediate level as they had had an English Language Placement Test (ELPT) before having IEC and they got band 4.0 up. The goal of the course was to enable the students to pass the ELPT with band 6.0 up as the requirement for starting their study program at UUM.

The course focuses on four skills. They are listening, reading, speaking and writing. Then, the class that we observed was reading class. The textbook that was used in this class was "Focus on IELTS", New Edition (O'Connell, 2010). Most of the students were from Arabic countries and only two of them were from Thailand. The Students were quite confident to speak in English even though they had problems in terms of pronunciation, grammar and vocabulary.

The class we observed covered a reading text about "Eating Up the Titanic" from "Focus on IELTS", New Edition 2010. The functional focus of the lesson was to discuss how to answer the reading text questions in ELPT or IELTS through skimming, scanning and guessing the word meaning in the text given. The formal objectives of the lesson were for students to comprehend the reading text in meaningful text and enable the students to answer the reading text 
questions given on the textbook. The teacher was Malaysian. He is one of the senior English teachers at The Language Center, Universiti Utara Malaysia (LC UUM). Additionally, he was very confidant, posed and caring about the students' abilities in terms of vocabularies. There was no Lesson Plan while he was teaching in this class.

Looking at the background of students, material or textbook and teacher we were interested to observe the activities inside the class. Therefore, here we provide the description of classroom activities that we observed from the beginning of the class on.

\section{Classroom Activities}

The lesson was very well executed. However, this teaching learning process was not essentially perfect. So, what we looked at might have had some elements, which we could take issue with. We took our seats at the left corner of the class so that we could see the whole class activities and observe the following series of classroom activities.

1. Without greeting the students and opening the class, Teacher (hereafter " $\mathrm{T}$ ") came to class and shared 2 pieces of paper to the students entitled "Eating Up the Titanic" and there were 14 questions on those two pieces of paper with one additional page as an exercise for the students before going to the 14 questions.

2. T began the 2-hour class with giving the general overview to the students (hereafter "Ss") about the questions that mentioned on the pieces of paper given. He was trying to make sure that the students had already known the style of the question about True, False and Not Given in questions 1-5, Filling Up the table in questions 6 - 10 and Multiple Choice Questions with Multiple Choice of Answers in question $11-14$.

3. Then, the $\mathrm{T}$ tried to call the students experience and knowledge in how to read the reading text. Look at the conversation between the teacher and students below.

T: Anybody can tell me what are the 3 skills in how to read the reading text?

T: .... (Waiting for the students' responses)

Ss: (keep silent)

T: the first one is Skimming, Scanning and the third is Intensive Reading. You look closely to the passage.

4. He then explained more about the Intensive Reading and informed the students that there was an exercise that related to not only skimming and scanning but also intensive reading on the text.

5. He then asked the students to go to the exercise on questions number 1 and he explained these questions, which were about True, False and Not Given style. The Ss then looked at the exercise and tried to understand what the $\mathrm{T}$ had said.

6. T then explained the whole types of questions in the exercise.

7. He then asked the Ss to look at the question Number 1, which was divided into "a" and "b" groups of questions. Then, he read the directions in the exercise loudly and asked the Ss whether they understood or not about the instructions.

T: Look at the Photo!!

Ss: (silent and look at the photo)

T: What do you see at the photo?

S: Ship.

Ss: (Silent)

T: you see the framework of the Ship.

8. He then explained the framework of the ship and the Ss just kept silent. Some of them were listening to what he said and some did not care about it.

9. He then continued to read the directions and asked the students to do what the directions were asking to do.

10. The teacher began to read the question no. 1 in "a" groups of questions. Then he asked the Ss to answer by reading the text entitled "Eating Up the Titanic". However, the Ss just kept silent then he gave the explanations about the question no. 1. He then gave yes/no question related to the question no. 1. And then interestingly the students responded. Finally he gave the answer of the question by himself and continued the questions until no. 6 with the same way and the same response from the Ss.

11. T tried to give the explanations about the unfamiliar words in the question using the body language.

T: What do you call a mountain of the ice?

Ss: (Silent)

$\mathrm{T}$ : Ice.......?

S: "Ice-Bark"

$\mathrm{T}$ : Iceberg... yes, iceberg is the answer.

T: where do you find the iceberg? Sea or island?

S: Sea 
T: yes, you cannot call it a mount. You call it iceberg. So, you can say a huge mass of ice. M $-\mathrm{A}-\mathrm{S}-\mathrm{S}$. (T spells it)

12. $\mathrm{T}$ then asked the students the question no. 1 in group "b" with reading the directions first. He started with no. 1 and then asked the students about the main words in that question. It was "rusticles". The Ss just kept silent and no answer from them.

13. T explained the meaning of the "rusticles" by giving the explanation about the word in details, e.g. dividing the word into two parts that are rust and icles. And then, T explained it more with elaboration by using body language and synonyms of the word.

14. T then asked the Ss the questions 1 through 4 and only one Student answered the questions and the others just kept silent. And then, the T answered the question by himself. This way was going on until question no. 4 .

15. T then asked the students about exercise no. 2 in group "a" by reading the direction first. Then, the Ss responded to his directions by looking at the paragraph and find the word that could help the Ss to guess the meaning of the words on questions 1 through 10 in group "a".

16. Ss then answered the question directly if they could find the answer on the paragraph given. $T$ responded to their answers and he also tried to answer the question by giving evidence from the paragraph. And then, $T$ explained the word on that question clearly by giving explanation in more details; giving the synonyms and antonyms of some words so that the students understood the meaning of those words. This way continued on until no. 10 in group "a" of question no. 2 .

17. T then continued the lesson by asking the students to look at the next question. He shared a piece of paper to each one of the Ss, which was related to question no. 2 in group "b". Ss looked at the question and tried to answer the question. The question was about matching the word given in the exercise no. 2 in "a" group with the explanation on the paper given by the $\mathrm{T}$.

18. T then continued the lesson by leading the Ss to answer the questions. He started with the word no. 1 in exercise no. 2 in-group "a", and found the matching explanation on the shared paper. $\mathrm{T}$ tried to answer the question and gave the explanation how to answer that question. It happened from no. 1 until no. 10 of the questions.

19. T then asked the students to go to the next exercise. He read the directions and the Ss listened to his explanation about the direction. Then, the $\mathrm{T}$ asked them to look at the task on the pages 66 and 67 that direction was given and tried to answer question no. 1 until no. 3 because there was a relation between the exercise and the task on page 66 to 67 . T and Ss answered the questions but the dominant one answering the question was the $\mathrm{T}$. He did not merely give the answer but he gave the evidence from the text about the provided answer. Hence, Ss understood clearly but no feedback from the Ss. This way was going on from question no. 1 to no. 3 .

20. Then, following the directions from exercise no. 4, the $T$ asked the students to do the task on page 66 to 67 . So, the Ss tried to answer quickly.

21. The $\mathrm{T}$ began to discuss the answer of the question no. 1 through no. 6 and the style of the questions was True, False and Not Given questions. He gave the explanations about the style of the questions first and after that he read the questions and asked the Ss about the answers. Only one student gave the answer and $\mathrm{T}$ asked where the student found the answer from. Then, $T$ continued with the next questions until no. 6 . He gave the answers if the Ss did not know them; he gave the evidence where he found the answer from in terms of the paragraph and line of the answer in the text.

22. T then continued the class with the task no. 6 to no. 10 which was completing the table. T asked the Ss to read the question first and then asked them to find out the words on the paragraph in the text. Ss did what the T asked. Then, the $\mathrm{T}$ tried to discuss the answers with Ss. He led the students to answer, and asked them to answer. While the students gave the answer, the $\mathrm{T}$ asked students to give evidence from where the students found the answer in what paragraph and line. If the Ss did not know the answer, he would give the answer, and directions to find the answer by showing the paragraph and line. Then, he gave explanations why the answer should have been so in terms of paraphrasing.

23. T then continued the activities to answer the multiple choice questions, which were from no. 11 into no. 14 . He asked the students to read the statements given first and after that find the answer. He read the statements then he asked the Ss whether they were true or not based on the text. The Ss just kept silent, and listened to him. Hence, the $\mathrm{T}$ gave the answer by himself and the evidence as well from the text.

24. While $\mathrm{T}$ was giving the explanations about the answers, there were some students late entering the class and he did not care about that. Interestingly, one of the students came 15 minutes before the class finished with her baby and the $\mathrm{T}$ did not care about that. Then, some students were listening to him and some were not because the class was going to be finished.

25. After finishing the task, he closed the class and asked the students to sign the attendance list. Then he went out of the class. 


\section{Methodology of Teaching Learning Process}

From the classroom activities, it can be virtually formulated what kinds of methods had been used in that class by analyzing the observation result based on the principle of the methods. In so doing, the results of the observation based on the previous classroom activities are listed in the table below.

\begin{tabular}{|c|c|c|c|}
\hline No & Observation result & Principle & Related Method \\
\hline 1 & $\begin{array}{l}\text { The goals of this teaching learning } \\
\text { process for students are to be able to } \\
\text { get the meaning of the text given and } \\
\text { answer the related questions. So, the } \\
\text { students focus on grammar and } \\
\text { meaning of the words. Students want to } \\
\text { pass the ELPT Test. (see activity 10.) }\end{array}$ & $\begin{array}{l}\text { A fundamental purpose of learning a language } \\
\text { is to be able to read literature written in it. } \\
\text { Literary language is superior to spoken } \\
\text { language. Students' study of the target culture } \\
\text { is limited to its literature and fine arts. } \\
\text { (Larsen-Freeman and Aderson, 2012:17) }\end{array}$ & $\begin{array}{l}\text { Grammar } \\
\text { Translation } \\
\text { Method (GTM) }\end{array}$ \\
\hline 2 & $\begin{array}{l}\text { The teacher's roles are more to explain } \\
\text { the words' meaning, giving directions } \\
\text { and answering the questions together } \\
\text { with the students. Then, the students } \\
\text { give their responses and discuss with } \\
\text { the teacher the answer of the question. } \\
\text { (see activities } 3 \text { to } 25 \text { ) }\end{array}$ & $\begin{array}{l}\text { The teacher and the students more like } \\
\text { partners in teaching learning process. } \\
\text { (Larsen-Freeman and Aderson, 2012:30) }\end{array}$ & $\begin{array}{l}\text { Direct } \quad \text { Method } \\
\text { (DM) }\end{array}$ \\
\hline 3 & $\begin{array}{l}\text { Teacher always gives the meaning of } \\
\text { the new word through target language. } \\
\mathrm{He} \text { explains the word by giving } \\
\text { examples, pictures, complete sentences } \\
\text { and synonyms and antonyms. (see } \\
\text { activities } 11 \text { to 13) }\end{array}$ & $\begin{array}{l}\text { Teacher demonstrates the meaning through the } \\
\text { use of realia, pictures or pantomime. Students } \\
\text { practice vocabulary by using new words in } \\
\text { complete sentence. (Larsen-Freeman and } \\
\text { Aderson, 2012:30) }\end{array}$ & DM \\
\hline 4 & $\begin{array}{l}\text { Students get the authentic material } \\
\text { regarding the reading text on IELTS } \\
\text { test. (see activity 1.) }\end{array}$ & $\begin{array}{l}\text { Whenever possible, authentic language -- } \\
\text { language as it is used in a real context - } \\
\text { should be introduced. } \\
\text { (Larsen-Freeman and Aderson, 2012: 119) }\end{array}$ & $\begin{array}{l}\text { Communicative } \\
\text { Language } \\
\text { Teaching (CLT) }\end{array}$ \\
\hline 5 & $\begin{array}{l}\text { The teacher gives the direction on } \\
\text { Target language. (see all the activities) }\end{array}$ & $\begin{array}{l}\text { The target language is a vehicle for classroom } \\
\text { communication, not just the object of study. } \\
\text { (Larsen-Freeman and Aderson, 2012: 120) }\end{array}$ & CLT \\
\hline 6 & $\begin{array}{l}\text { The interaction is from teacher to } \\
\text { students just a little from students to } \\
\text { teacher and the student talks to others } \\
\text { as well. (see activities } 3,7,10,11,14 \text {, } \\
16,19,21 \text {, and 22) }\end{array}$ & $\begin{array}{l}\text { The initiation of the interaction goes both } \\
\text { ways although the latter is often teacher } \\
\text { directed. Students converse with one another } \\
\text { as well (Larsen-Freeman and Aderson, } \\
2012: 31 \text { ) }\end{array}$ & DM \\
\hline 7 & $\begin{array}{l}\text { The teacher does not care about the } \\
\text { students' feeling. (see activity } 24 \text { ). }\end{array}$ & $\begin{array}{l}\text { There is no principle of the method, which } \\
\text { relate to this era. (Larsen-Freeman and } \\
\text { Aderson, 2012: } 19,31 \& 45 \text { ) }\end{array}$ & $\begin{array}{l}\text { GTM, DM and } \\
\text { Audio } \quad \text { Lingual } \\
\text { Method (ALM) }\end{array}$ \\
\hline 8 & $\begin{array}{l}\text { The teacher and the students use target } \\
\text { language because the teacher has } \\
\text { different first language with the } \\
\text { students. }\end{array}$ & $\begin{array}{l}\text { Language is primarily spoken not written. } \\
\text { Students' native language should not be used } \\
\text { in the classroom. } \\
\text { (Larsen-Freeman and Aderson, 2012:31) }\end{array}$ & DM \\
\hline 9 & $\begin{array}{l}\text { The teacher teaches reading skill and } \\
\text { he focuses on the word meaning and } \\
\text { paraphrases the words. (see activities } 7 \text {, } \\
8,11,12,13,15,16,17,18,22,23 \text { and } \\
24 \text {. }\end{array}$ & $\begin{array}{l}\text { Vocabulary is emphasized over grammar. } \\
\text { Although work on all four language skills } \\
\text { occurs from the start, oral communication is } \\
\text { seen as basic. (Larsen-Freeman and Aderson, } \\
\text { 2012: } 31 \text { ) }\end{array}$ & DM \\
\hline 10 & $\begin{array}{l}\text { Teacher does not arrange the formal } \\
\text { test on the teaching learning process at } \\
\text { that day. (See all activities) }\end{array}$ & $\begin{array}{l}\text { No formal test is taken from the classroom } \\
\text { activities. (Larsen-Freeman and Aderson, } \\
\text { 2012:31,46, and 64) }\end{array}$ & $\begin{array}{l}\text { DM, ALM and } \\
\text { Silent Way. }\end{array}$ \\
\hline 11 & $\begin{array}{l}\text { The teacher asks the students to answer } \\
\text { the exercises and questions correctly. } \\
\text { Then, he supplies the correct answer if } \\
\text { the students do not know the answer or } \\
\text { the students give the wrong answer. } \\
\text { (see activities } 3,11,12 \text {, and 14) }\end{array}$ & $\begin{array}{l}\text { It is very important that students get the } \\
\text { correct answer and errors lead to the formation } \\
\text { of bad habits. } \\
\text { (Larsen-Freeman and Aderson, 2012: } 18 \text { \& } \\
\text { 42) }\end{array}$ & GTM and ALM \\
\hline
\end{tabular}

From the above data, there are 5 methods were applied in the classroom activities. The principles that are related to Direct Method was the most often appeared in that teaching learning process which reached 7 principles and second 
position was reached by two methods namely Audio Lingual Method and Grammar Translation Method. Both got 3 principles and the last was Silent Way with one principle. Then, the second last one was Communicative Language Teaching with 2 principles. It means that dominant method used in classroom activities was Direct Method.

For every tiny moment of those classroom activities, certain choices were made. Some methodological issues were raised. The questions that appeared from those certain choices, which were made by the teacher, are as follows:

a) Why did the T distribute the "Eating Up Titanic" text to the Ss?

b) T recalled the Ss understanding about 3 major skills in reading a text (see activity 3 ). Why did the $\mathrm{T}$ do this?

c) Why did $\mathrm{T}$ explain more about the directions in the exercises and questions?

d) Why did $\mathrm{T}$ do a small talk about the Titanic by asking the Ss knowing about it? (See activity 2)

e) Why did the $\mathrm{T}$ give the yes/no questions to Ss to answer the exercise no.1?

f) "You can say a huge mass of ice. M-A-S-S. (See activity 11). Why did T spell the word?

g) $\mathrm{T}$ asked the students to look at Question first before going to the text (see activities 7 to 23). What do you think the benefit of that way is?

h) Why did $\mathrm{T}$ use 5 methods at the same time in classroom activities?

i) A last question: as you look back over the lesson we have just observed. Do you think the goal and initial objective of the lesson was accomplished? Or it was getting another thing from the class.

To answer those issues or questions, we should refer to the principles of teaching reading skill, theory and latest result of research in terms of reading skill. In so doing, the discussion is provided in the next section regarding the issues above.

\section{Discussion}

Regarding the material, the "Eating Up Titanic" is the familiar topic that existed in "Focus on IELTS" New Edition (O'Connell, 2010: 65-66) textbook. This authentic material will motivate students to get their goal in Teaching Learning Process. In order to make the materials become motivating for students, it should be relevant to the goal of the students (Brown, 2007:373). Besides that, Tamo (2009:75) said that one of the advantages of authentic material is that authentic materials have a positive effect on learner motivation. Then, the teacher tried to make students understand about the strategy to read a text. This is a good way for the students before reading since among the 8 principles are "Plan on Pre-reading, During-Reading and After Reading. Before reading, T should spend some time to introduce topic, encourage skimming, scanning, predicting and activating schemata (Brown, 2007: 375). It is also related to the c) question in which the teacher tried to get them understand and have prior knowledge before reading the text since the prior knowledge of the text is very beneficial for the students during the reading text. Karla (2013) stated that the prior knowledge of readers is the single most important component in the reading process. Next, on the d), e) and f) questions teachers tried to communicate with the students in order to call the students overview about the text based on their experience and intelligence that is called Top Down strategy and also to go through to the inside of the text so that students understand the meaning, and the words in the text that is called Bottom Up strategy (Brown, 2007:358). Haradasht (2013:238), on his research, concluded that Bottom Up is better for introvert learners while Top Down is better for extrovert learners. Meanwhile, the teacher might not know the kinds of students in terms of being extrovert and introvert so the better way is to use both of the strategies in the same time. For the question g), teacher tried to encourage with the assessment principle. Brown (2007:376) stated that one of the good assessments in reading skill is to ask the students to answer the questions of the passage. Then, in h) question, using more than one method in teaching learning process commonly happens in classroom activities. Some researchers believe it is very good to use the variety of the teaching principle in classroom activities. Ransom et al. (1999) stated that there is no single method or single combination of methods that can successfully teach all learners to read. Therefore, teachers must have a strong knowledge of multiple methods for teaching reading and a strong knowledge of the learner in their care so they can create the appropriate balance of methods needed for the learner they teach. So, it is a better way to combine the 5 methods as one method may have many weaknesses such as Direct Method itself. Its success may have more a factor of the skill and personality of the teacher than of the methodology itself (Brown, 2007:22). Last but not least, it can be stated that the goal was not perfectly got by the students since the students normally accept all things from the teacher. There was no initiative from the students. Therefore, in terms of the methods applied in this class, it can be said that there were of good varieties. The principles used in classroom activities were also good enough. The teacher arranged them clearly. He also tried to lead the learners to skim, ask question, read text while looking for answer, reprocess the main points of text and assess the important point (see activities 9 to 23). His technique was in fact the same with SQ3R sequence. Brown (2007:375) stated that one effective series of procedures of approaching a reading text has come to be labeled the SQ3R technique, a process which consist of Survey, Question, Read, Recite, and Review.

\section{Conclusion}

All in all, the methodologies used in this classroom were 5 methods but the dominant one was Direct Method. To combine more than one method is one of the best ways for the teaching reading skill to the learners. In terms of this, the teaching learning process was done well. Regarding the principles that teacher applied in this classroom, activities were very good since the students were able to understand the general meaning of the text and also were able to answer the questions in the text given correctly because of that it can be concluded that they could get the vocabulary and the 
grammar patterns in the text clearly. From both methodology and principles, these classroom activities were done well even though the initiative from the learners needs to be improved the get the better initial objective or goal.

\section{References}

Brown, H. D. (2007). Teaching by Principle; An Interactive Approach to Language Pedagogy. Third Edition. New York: Pearson Longman.

Haradasht, P.N. (2013). The Comparative Effect of Top-down Processing and Bottom up Processing through TBLT on Extrovert and Introvert EFL Learners' Reading Comprehension. International Journal of Applied Linguistics \& English Literature. 2 (5) $229-240$

Larsen-Freeman, D and Anderson, M. (2011). Techniques \& Priciples in Language Teaching. Oxford: Oxford University Press.

Porter, K. (2013, November 20). Pre-reading Strategies. Retrieved on November 21, 2013 from http://departments.weber.edu/teachall/reading/prereading.html

Ransom, K. A. et al. (1999). Using Multiple Methods of Beginning Reading Instruction; A Position Statement of the International Reading Association. Newark: International Reading Association. Retrieved (November 21, 2013) from http://www.reading.org/Libraries/position-statements-and-resolutions/ps1033_multiple_methods.pdf.

Tamo, D (2009:75). The Use of Authentic Materials in Classrooms. Journal of LCPJ. 2 (1 ) 74-78. 